minus blue filter is giving improved definition and it is suggested that a green filter should be tried.

Considerable experinentation with infra-red photography has been conducted, but the results are not very promising from the forestry standpoint.

Provision is being made through the co-operation of the Forest Service, Topographic and Air Survey Bureau and the Royal Canadian Air Force for twenty hours experimental photography during the coming year to determine if possible the comparative value of the following:

(1) Spring, summer, autumn and winter photographs

(2) Verticals, horizon obliques, and steep obliques

(3) Panchromatic and infra-red films

(4) Minus blue and green filters

(5) Altitudes of 5000 and 10,000 feet.

Mr. H. E. Seely has made considerable progress in designing the following instruments:

(1). An adjustahle stereoscope by which photos of different angles, tilts and scales can be made to coincide.

(2) A camera which will record the horizon on steep obliques.

(3) A projector to permit of the plotting of type boundaries and other features on aerial photographs directly on a map.

\title{
REPORT OF UTILIZATION COMMITTEE CANADIAN SOCIETY OF FOREST ENGINEERS
}

\author{
By T. A. MCELHANNEY \\ JANUARY-1936
}

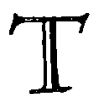
HE UTILIZATION Committce hasn't yet started to function as a Committee. I was away nearly all summer and since my return Mr. Fellows, the Secretary of the Committec, has, unfortunately, been rather seriously ill. I understand that no Comnittee was appointed, but that the selection of this Committee was left to the Chairman and Secretary The members of the Committee have not yet heen appointed, tho' some thought has been given to this. Until the personnel of the Committee is decided, no definite programme can be drawn up for the Committee.

From the standpoint of the technical phases of co-operation, there already exist several active organizations. The Forest Products.Laboratories work in very close co-operation with the Pulp and Paper Industry through the Joint 
Administration Committee of the Pulp and Paper Research Institute, and also through the Woodlands and Technical Sections of the Pulp and Paper Association. Practically the whole programme of the Pulp and Paper Division is made up of projects requested by the industry. In addition, the main Laboratories have carried out or have on hand a number of projects with the Woodlands Section of the Pulp and Paper Association, including log. sinkage, the efficiency of buck-saws, the design of logging equipment, (principally sleighs) the variation in density of pulpwood species in Eastern Canada, and the deter- ioration through decay of pulpwood in block piles.

- Co-operation with lumber associations has also been actively organized for a number of years. In order to make progress in any direction, the first and most important consideration is the hearty co-operation of those organizations which should co-operate. With this thought in mind, and in order that the Laboratories and at the same time that Laboratory officers might more thoroughly appreciate the practical problems of the industries, a suggestion made a few years ago to the Canadian Lumbermen's Assocjation that a co-operative committee be set up, met with instant response, and the Lumbermen's Research Committee was brought into being. This Committee initiated the idea of publishing a book on Canadian Woods to serve to some extent as a handbook for the Canadian lumber industry. After about two years' work by members of the Laboratory staff, the book on "Canadian Woods, Their Properties and Uses" was issued last spring. The Committee also asked the Laboratories to look into the question of blue-stain in white pine, which in normal years on the basis of the 1929 cut, was causing a loss of about a quarter of a million dollars a year, and in years of high humidity a loss as high as a million dollars a year. The Laboratories carried on a series of tests with chemicals which had shown promise in other districts, principally in the southern pine district, and as a result recommended the dipping of upper grades in the solution which gave best results. Dipping or spraying equipment has since been established in practically all large white pine mills with marked reduction in loss from blue-stain. The Research Committee has also asked for a special study on brown-stain in white pine, and has taken active interest in the study of red stain in jack pine. Through the cooperation of the Research Committee, a series of lectures and demonstrations, comprising a week's course, was given in the Laboratories last spring, and will probably be given again this year. This Committet has also been active in the revision of Building Codes and particularly : in: the establishment of standard structural grades for all species of Canadian softwoods through the Canadian Engineering Standards Association. These are a few of the specific problems which have engaged the attention of the Lumbermen's Research Committee. Whenever possible, it has been the Laboratories' practice to call. in the Research Committee to go over our proposed Programme of Work for the year. This 
has frequently involved a full day's discussion, which has been of the greatest advantage from a practical standpoint, but possibly even more so from a psychological standpoint.

So far as the work of the Utilization Committee of the Canadian Society of Forest Engineers is concerned, it would, therefore, seem advisable not to duplicate work already served adequately by other organizations, but rather to pay attention to utilization problems more closely related to forestry, as it is generally understood, or in other words, to border-line problems. The most important problem in my opinion in forestry is to properly relate or co-ordinate forestry and utilization, and to broaden in the minds of foresters and others the conception of forestry.

While the rounding out of a programme will have to await the attention of the Committee when formed, a few problems suggest themselves, as for example:

(a) The utilization of logging and mill waste by chemical or mechanical conversion, waste for fuel, etc.

(b) The use of species such as white birch, poplar, and certain other hardwoods.

(c) The use of built up members in large structures due to the increasing difficulty of obtaining large timbers in some districts.

(d) The use of wooden connectors in the design of wonden structures.

(e) Charcoal or wood as a fuel for internal combustion engines in logging operations.

(f) Improvements in logging and milling equipment. Greater mechanization to reduce costs and permit competition with substitutes.

(g) The species and quality of timber which should be produced in the forest, to meet requirements of the lumber industry.

To adequately deal with some of these problems, there must be a combination of effort of foresters and utilization officers. So far as the Committees of this Society are concerned, the Utilization and Operation Committees will have to work together in many instances in devising methods of attack on some of these problems.

\section{REPORT OF THE SUB-COMMITTEE ON WOODS OPERATIONS C.S.F.E.}

\section{Personnel}

$$
\text { JANUARY-1936 }
$$

The Committee at present is made up by Messrs. A. M. Koroleff (Chairman), Howard Kennedy, L. Schuelt, B. V. Avery, and J. D. B. Harrison 